\title{
MORPHOLOGICAL AND ANATOMICAL TRAITS OF SHORT-LIVED RYEGRASS
}

\author{
Vilma Kemešytè, Nijolè Lemežienè, Vaclovas Stukonis, and Juozas Kanapeckas \\ Lithuanian Research Centre for Agriculture and Forestry, Institute of Agriculture, \\ Instituto al. 1, Akademija, Kèdainiai distr. LT-58344, LITHUANIA; \\ vilma@Izi.It
}

Communicated by Isaak Rashal

The ryegrass species are visually similar, and therefore, correct identification of short-lived species is very important in breeding work. The aim of the current study was to identify short-lived ryegrass species and subspecies using anatomical and morphological characteristics. The study was carried out at the Institute of Agriculture, Lithuanian Research Centre for Agriculture and Forestry (during 2007-2010). The assessment of morphological and anatomical traits showed that average values for species diverged, but values for individual plants often overlapped between species. One of the most characteristic traits of Lolium. x hybridum was darker leaf colour (6.7 score). Awns are characteristic for both Lolium multiflorum subspecies, while perennial ryegrass plants are awn-less. Lolium $\mathrm{x}$ hybridum has a short awn or no awn, depending on which parental (Lolium perenne or Lolium multiflorum) species trait was stronger. As a result, identification of short-lived species according to this trait is difficult, and sometimes impossible. Analysis of leaf cross-section of short-lived ryegrass species indicated that a characteristic of Lolium multiflorum subsp. multiflorum was conjugation of sclerenchyma fibres not only in the central but also in lateral bundles, in contrast with Lolium multiflorum subsp. italicum and Lolium $\mathrm{x}$ hybridum. Lolium multiflorum subsp. multiflorum. This difference occurs only at the inflorescence emergence stage.

Key words: short-lived ryegrass, morpho-anatomical traits.

The ryegrass (Lolium spp.) genus comprises about ten species (Terrell, 1968; Цвелев, 1976). The two most common forage ryegrass species are Lolium perenne L. and Lolium multiflorum Lam. (Humphreys et al., 2010). The hybrid of these ryegrasses, Lolium hybridum Haussskn., is less common.

Italian ryegrass includes the biennial L. multiflorum subsp. italicum and annual Lolium multiflorum subsp. multiflorum (Reed et al., 2000). Some authors discriminate Lolium multiflorum subspecies italicum or multiflorum (Lenuwiet et al., 2002; Humphreys et al., 2010), others consider only the species Lolium multiflorum (Lacefield et al., 2003).

Lolium multiflorum subsp. italicum grows rapidly, has a long growing season, produces high yield, has good feed value, and therefore, is widely used not only for grazing but also for hay, haylage and silage production (Wilkins, 1991; Reheul et al., 2003). This ryegrass species is grown in pure stands or in mixtures with clover (Trifolium spp. L.) (Lenuweit et al., 2002).

Lolium multiflorum subsp. multiflorum was undeservedly forgotten, although annual ryegrasses in a pure stand or in mixture with oat (Avena sativa L.), vetch (Vicia sativa L.) or annual clover (Trifolium spp.) can be suited for re- seeding of decayed perennial grasses and winter cereal crops (Humphreys et al., 1998; de Ruiter et al., 2002; Opitz v. Boberfeld et al., 2005; Cojocariu et al., 2008).

Seeking to improve resistance to adverse growing conditions, Lolium multiflorum was crossed with Lolium perenne, which produced Lolium x hybridum (Peeters, 2004). Lolium $x$ hybridum is higher-yielding than Lolium perenne and more resistant to adverse winter conditions than Lolium multiflorum (Hannaway et al., 1999a; 1999b; Reed et al., 2000).

Breeding programmes for short-lived ryegrasses are being carried out in Lithuania to create new varieties that are adapted to local conditions. The ryegrass species are visually similar, and therefore, correct identification of shortlived species is very important in breeding work. The aim of the current study was to identify short-lived ryegrass species and subspecies using anatomical and morphological features.

A collection of short-lived ryegrass species, including Lolium (L.) multiflorum subsp. multiflorum varieties (24), Lolium (L.) multiflorum subsp. italicum (72) and Lolium (L.) x hybridum (24) varieties, was set up in experimental fields of the Institute of Agriculture, Lithuanian Research 
Centre for Agriculture and Forestry. Eighteen individuals were planted per plot (nine plants in two rows) at a distance of $50 \times 50 \mathrm{~cm}$, using a randomised complete block design with three replications.

The short-lived ryegrass species were identified by morphological and anatomical analysis (Natkevičaitė-Ivanauskienè, 1963; Цвелев, 1976; Прокудин и др., 1977).

For the analysis of morphological and anatomical traits, herbaria were collected for flowering individuals in the first ( $L$. multiflorum subsp. multiflorum) and second years of growth (L. multiflorum subsp. italicum ir L. $x$ hybridum). Plant height $(\mathrm{cm})$, leaf colour (score), length and width of flag leaf $(\mathrm{cm})$, inflorescence, glume, lemma, awn and spikelet length $(\mathrm{mm})$ were measured, and spikelet number per inflorescence and number of vascular bundles were counted.

For anatomical leaf analyses, cross-sections of leaves were taken from the herbarium material. Conjugation of sclerenchyma fibres was determined by a biological microscope.

Computer software STAT adapted by P. Tarakanovas in Visual Basic for use as a macro-programme in EXCEL was used for calculation of coefficient of variation (CV) and standard error (Tarakanovas and Raudonius, 2003).

Analysis of leaf cross-section showed that L. multiflorum subsp. italicum and L. $x$ hybridum could be characterised by conjugation of sclerenchyma fibres in the central and 2-3 lateral bundles (Fig. 1). L. multiflorum subsp. multiflorum sclerenchyma fibres conjugated in the central and in all lateral bundles.

Analysis of morphological and anatomical traits showed average differences of short-lived ryegrass species (Table 1).

The assessment of morphological-anatomical traits showed their average values differed, but those of individual plants often overlapped between varieties.
High or moderate variation of morphological traits was observed for short-lived ryegrass varieties of different origin (Table 1). An exception was length of lower glume. This trait was most stable. In contrast, awn length was most polymorphic. In breeding, high variation between varieties is a positive indicator (Jafari et al., 2003). Currently, this is especially important, since registration of a ew variety requires traits to be not only stable, but also distinct from other varieties.

The ryegrass species had light green to dark green leaf colour (Anonymous, 2006), depending on short-lived ryegrass species. Lolium $x$ hybridum had a significantly darker leaf colour, compared with Lolium multiflorum, as described earlier (Richardson 2004). Leaf colour is important when ryegrasses are used in mixtures for turf. This trait is not important when ryegrasses are grown for forage. Darker leaf colour can be obtained when turfs are fertilised with mineral nitrogen (Ahmad et al., 2003). Lolium x hybridum is often used for turf (Richardson, 2004), while Lolium multiflorum subsp. italicum is less popular. Italian ryegrass was initially used as the primary grass in overseeding due to its rapid germination, establishment and availability, but it had poor cold and heat tolerance, poor density and texture, and required frequent mowing due to its rapid growth (Richardson, 2004). Lolium multiflorum subsp. multiflorum is produces dense lawns in the sowing year (Cosgrove et al., 1999).

The short-lived ryegrass species are visually similar to each other, and also to perennial ryegrass. Therefore, it is difficult to visually distinguish plants in the infancy stage (before inflorescence emergence). The spikelets of Lolium multiflorum have short awns in the head of the glume. Perennial ryegrass does not have awns. The obtained data confirmed observations of S. A. Mirjalili et al. (2008). The difference in awn features appears after inflorescence emergence. L. $x$ hybridum has a short awns or no awn (Fig. 2 ). This trait depends on which parental (L. perenne or

Table 1

MORPHOLOGICAL AND ANATOMICAL TRAITS OF SHORT-LIVED RYEGRASS SPECIES, AVERAGE IN 2007-2009

\begin{tabular}{|c|c|c|c|c|c|c|}
\hline \multirow[t]{3}{*}{ Trait } & \multicolumn{4}{|c|}{ Lolium multiflorum } & \multirow{2}{*}{\multicolumn{2}{|c|}{ Lolium x hybridum }} \\
\hline & \multicolumn{2}{|c|}{ subsp. multiflorum } & \multicolumn{2}{|c|}{ subsp. italicum } & & \\
\hline & $\overline{\mathrm{X}} \pm \mathrm{SD}$ & $\mathrm{V} \%$ & $\overline{\mathrm{X}} \pm \mathrm{SD}$ & $\mathrm{V} \%$ & $\overline{\mathrm{X}} \pm \mathrm{SD}$ & $\mathrm{V} \%$ \\
\hline Plant height, cm & $49.6 \pm 1.20$ & 27.17 & $51.6 \pm 0.47$ & 12.97 & $50.2 \pm 0.62$ & 11.84 \\
\hline Leaf colour (points) & $5.3 \pm 0.26$ & 26.77 & $5.1 \pm 0.16$ & 26.79 & $6.7 \pm 0.42$ & 30.28 \\
\hline Length of flag leaf, cm & $12.6 \pm 0.37$ & 33.19 & $14.0 \pm 1.04$ & 28.57 & $17.1 \pm 0.45$ & 25.01 \\
\hline Number of bundles & $21.0 \pm 2.02$ & 27.18 & $19.3 \pm 1.35$ & 19.78 & $19.3 \pm 1.18$ & 21.19 \\
\hline Inflorescence length, cm & $21.0 \pm 0.37$ & 20.17 & $26.1 \pm 0.93$ & 13.84 & $22.6 \pm 0.42$ & 17.83 \\
\hline Number of spikelets & $16.8 \pm 0.30$ & 20.25 & $23.9 \pm 0.92$ & 14.93 & $19.6 \pm 0.28$ & 13.81 \\
\hline Spikelet length, cm & $2.3 \pm 0.11$ & 13.56 & $2.1 \pm 0.08$ & 10.75 & $2.0 \pm 0.10$ & 16.36 \\
\hline Length of lower glume, $\mathrm{cm}$ & $0.7 \pm 0.02$ & 7.33 & $0.8 \pm 0.05$ & 17.17 & $0.8 \pm 0.02$ & 9.20 \\
\hline Length of upper glume, $\mathrm{cm}$ & $1.1 \pm 0.04$ & 10.68 & $1.0 \pm 0.08$ & 22.06 & $1.1 \pm 0.06$ & 17.58 \\
\hline Number of flowers & $12.6 \pm 0.65$ & 14.63 & $12.0 \pm 0.76$ & 17.82 & $10.5 \pm 0.44$ & 14.36 \\
\hline 1000 seed weight, $g$ & $3.4 \pm 0.17$ & 18.46 & $4.1 \pm 0.19$ & 32.06 & $4.2 \pm 0.15$ & 23.47 \\
\hline
\end{tabular}




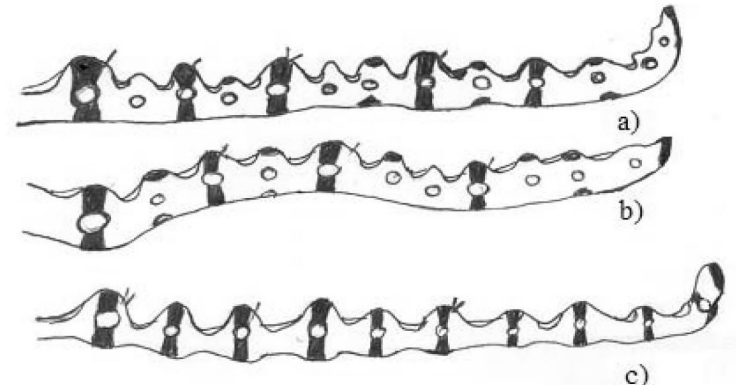

Fig. 1. Leaf cross-sections of short-lived ryegrass species, 2008-2009. Letters denote different species: a, Lolium multiflorum subsp. Italicum; b, Lolium x hybridum; c, Lolium multiflorum subsp. multiflorum.

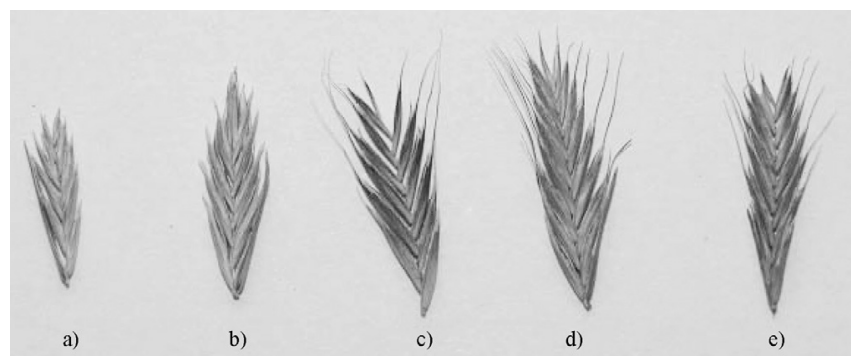

Fig. 2. Spikelets of ryegrass: a, Lolium perenne; b, Lolium x hybridum (type of Lolium perenne); c, Lolium $x$ hybridum (type of Lolium multiflorum); d, Lolium multiflorum subsp. italicum; e, Lolium multiflorum subsp. Multiflorum.

L. multiflorum) species traits are stronger (Ryan et al., 2007). As a result, identification of short-lived species according to this trait is difficult, and sometimes impossible.

Literature sources indicate that weight of 1000 seeds of Lolium multiflorum subsp. italicum is $2.5-4.6 \mathrm{~g}$, Lolium $x$ hybridum - 2.0-3.5 g and Lolium multiflorum subsp. Multiflorum - 2.5-4.5 g (Venuto, 2002; Peeters, 2004). Ploidy has an important influence on weight of seeds. Diploid varieties have smaller, and tetraploid varieties have larger seeds. A similar number diploid and tetraploid varieties of both subspecies of Lolium multiflorum were investigated. However, many varieties of Lolium $x$ hybridum were tetraploid. This might explain why the 1000-seed weight of Lolium $x$ hybridum was slightly higher than that given in literature.

In literature, Lolium multiflorum is mostly compared with Lolium perenne (Bennet et al., 2000; Mirjalili et al., 2008; Brown et al., 2009). Lolium multiflorum is taller and has wider leaves and longer glumes than Lolium perenne. Generally, Lolium multiflorum inflorescences are larger than those of Lolium perenne, and have more spikelets, more florets per spikelet and larger seeds. This can explain why Lolium $x$ hybridum showed mostly intermediate results compared with the parental species. However, Lolium $x$ hybridum is a hybrid between perennial and Italian ryegrass, and therefore, depending on the variety, can be similar to both parental species.

Short-lived ryegrass species differ according to the conjugation of sclerenchyma fibres in leaf vascular bundles: for
Lolium multiflorum subsp. multiflorum, sclerenchyma is conjugated in all bundles, for Lolium $x$ hybridum and Lolium multiflorum subsp. Italicum - in central and in every 2-3 lateral bundles. This difference occurs only at the inflorescence emergence stage when sclerenchyma is formed. The schlerenchyma is conjugated only in the central bundle in young plants of all species.

Bennett et al. (2000) and Mirjalili et al. (2008) distinguished Lolium perenne and Lolium multiflorum species, although introgression between them is possible and some characters are similar between the species. As a result, morphological traits of short-lived ryegrass species (especially of individual plants) mostly are similar betwen the subspecies Lolium multiflorum and Lolium $x$ hybridum.

\section{ACNOWLEDGMENTS}

The paper presents research findings, which have been obtained in the long-term research programme "Genetics and purposeful change of genotypes of agricultural and forest plants" implemented by the Lithuanian Research Centre for Agriculture and Forestry.

\section{REFERENCES}

Anonymous (2006). Guidelines for the conduct of tests for distinctness, uniformity and stability. Ryegrass, $\mathbf{1}$. UPOV - International union for the protection of new varieties of plants. $26 \mathrm{pp}$.

Ahmad, I., Asalma Khan, M., Qaim, M. (2003). Growth and development of different turfgrasses as influenced by nitrogen application and leaf nitrogen contents. Int. J. Agricult. Biol., 2, 175-178.

Bennett, S. J., Hayward, M. D., Marshall, D. F. (2000). Morphological differentiation in four species of the genus Lolium. Gen. Res. Crop Evol., 47, 247-255.

Brown, R. N., Barker, R. E., Warnke S. E., Cooper, L. D., Brilman, L. A., Rouf Mian, M. A., Jung, G., Sim, S.-C. (2009). Identification of quantitative trait loci for seed traits and floral morphology in a field-grown Lolium perenne x Lolium multiflorum mapping population. Plant Breeding, 129, 29-34

Cojocariu, L., Moisuc, A., Radu, F., Marian, F., Horablaga, M., Bostan, C., Sarateanu, V. (2008). Qualitative changes in the fodder obtained from forage legumes and Lolium multiflorum in the ecological conditions of Eastern europe. Options Méditerranéennes, A (79), 167-171.

Cosgrove, D., Casler, M., Undersander, D. (1999). Ryegrass types for pasture and hay. Agronomy advice FC. APA-style citation of Electronics resources. Retrieved 10 January 2006,

from http://www.uwex.edu/ces/forage/pubs/ryegrass.htm.

De Ruiter, J. M., Hanson, R., Hay, A. S., Armstrong, K. W., Harrison-Kirk, R. D. (2002). Whole crop cereals for grazing and silage: Balancing quality and quantity. Proc. New Zealand Grassland Assoc., 64, 181-189.

Hannaway, D., Fransen, Z., Cropper, J., Teel, M., Chaney, M., Griggs, T., Halse, R., Hart, aj., Cheeke, P., Hansen, D., Klinger, R., Lane, W. (1999a). Annual ryegrass (L. multiflorum L.). APA-style citation of Electronics resources. Retrieved 6 February 2007,

from http://eesc.orst.edu/agcomwebfile/ edmat/html/pnw/pnw501.

Hannaway, D., Fransen, Z., Cropper, J., Teel, M., Chaney, M., Griggs, T., Halse, R., Hart, aj., Cheeke, P., Hansen, D., Klinger, R., Lane, W. (1999b). Perennial ryegrass (L. perenne). APA-style citation of Electronics resources. Retrieved 6 February 2007,

from http://eesc.orst.edu/agcomwebfile/edmat/ html/pnw/pnw503. 
Humphreys, J., Jansen, T., Culleton, N., MacNaeidhe, F. S. (1998). Comparison of annual herbage yield, botanical composition and mineral content of swards of perennial ryegrass sown with white and red clover. Irish J. Agricult. Food Res., 37 (2), 159-172.

Humphreys, M., Feuerstein, U., Vandewalle, M., Baert, J. (2010). Ryegrasses. In: Fodder Crops and Amenity Grasses (pp. 211-260). Boller, B., Posselt, U., Veronesi, F. (eds.). Springer Science+Business Media.

Jafari, A., Hessamzadeh, S. M., Abdi, N., Seedi, M. (2003). Genetic variation for yield and morphological traits in 20 genotypes of Italian ryegrass (Lolium multiflorum) grown as spaced plants. Chech J. Gen. Plant Breed., 39, 41-47.

Lacefield, G., Collins, M., Henning, J. et al. (2003). Annual ryegrass. 9. APA-style citation of Electronics resources. Retrieved 21 February 2007, from http//www.ca.uky.edu.

Lenuweit, U., Gharadjedaghi, B., Sü_er, M., Schops, K., Blew, J., Ridder, S. (2002). Biologische Basisdaten zu Lolium perenne, Lolium multiflorum, Festuca pratensis und Trifolium repens.

http://www.leader-alpenvorland.at/gemeindeamt/download/ 223421260_1.pdf.

Mirjalili, S. A, Bennet, S. J., Poorazizi, E. (2008). A phenetic analysis on the genus Lolium (Poaceae) in Iran. Plant. Syst. Evol., 274, 203-208.

Natkevičaitė-Ivanauskienè M. (1963). Family Graminea. In: Bagdonaitè, A., Galinis, V., Jankevičienè, R., Lekavičius, A., NatkevičaitèIvanauskienė, M., Pipinys, J., Purvinas, E., Ribokaitė, R., Snarskis, A., Stancevičius, A., Šarkinienè, S. 1 (eds.). Flora of the Lithuanian SSR, Vol. 2 (pp. 277-282) (in Lithuanian).

Opitz von Boberfeld, W., Beckmann, E., Laser, H. (2005). Nitrogen transfers from Vicia sativa L. and Trifolium resupinatum $\mathrm{L}$. to the companion grass and the following crop. Plant Soil Environ., 51 (6), 267-275.

Peeters, A. (2004) (ed.). Wild and Sown Grasses. Profiles of a Temperate Species Selection: Ecology, Biodiversity and Use, 190-206.
Reed, K. F. M., Culvenor, R., Jahufer, Z., Nichols, P., Smith, K., Williams, R. (2000). Progress and Challenges: Forage breeding in temperate Australia. In: Spangenberg, G. (ed.). Molecular Breeding of Forage Crops. Proceedings of the 2nd International Symposium, Molecular Breeding of Forage Crops. 19-24 November 2000 (pp. 303-316). Lorne and Hamilton, Victoria, Australia.

Reheul, D., Baert, J., Ghesquiere, A. (2003). Progress in breeding perennial fodder grasses. In search of tetraploid ryegrass with a higher dry matter content (DMC). Czech J. Gen. Plant Breed., 39, 54-56.

Richardson, M. D. (2004). Morphplogy, turf quality, and heat tolerence of intermediate ryegrass. HortScience, 39 (1), 170-173.

Ryan, E., Mullins, E., Burke, J., Downes, M., Meade, C. (2007). Tracing field hybridization in Ryegrass species using microsatellite and morfological markes. Environ. Biosafety Res., 5, 111-117.

Tarakanovas, P., Raudonius, S. (2003). The Program Package „Selekcija“ for Processing Statistical Data. Akademija. 56 pp. (in Lithuanian).

Terrell, E. E. (ed.) (1968). A taxonomic revision of the genus Lolium. In: Technical Bulletin of the United States Department of Agriculture. No. 1392. Washington: United States Department of Agriculture.

Venuto, B. C., Redfearn, D. D., Pitman, W. D., Alison, M. W. (2002). Seed variation among annual ryegrass cultivars in south-eastern USA and the relationship with seedling vigour and forage production. Grass Forage Sci., 57, 305-311.

Wilkins, P. W. (1991). Breeding perennial ryegrass for agriculture. Euphytica, 52, 201-214.

Прокудин Ю., Вовк А., Петрова О. А., Ермоленко Е. Д., Верниченко Ю. (1977). Злаки Украины [Graminea of Ukraine]. Киев: Наукова Думка. c. 320-327 (in Russian).

Цвелев, Н. Н. (1976). Злаки ССCP [Graminea of USSR]. Ленинград: Наука. 788 с. (in Russian).

Received 1 June 2012

\section{İSMŪŽA AIREN̦U MORFOLOG̣ISKĀS UN ANATOMISKĀS PAZĪMES}

Aprakstìtas morfoloğiskās un anatomiskās pazīmes vairākām īsmūža airenes sugām (Lolium multiflorum subsp. multiflorum, Lolium multiflorum subsp. italicum and Lolium $\times$ hybridum), tās audzējot Lietuvas apstākḷos. 